\title{
The DNA barcode of red fruit pandan (Pandanaceae) cultivar from Wamena, Papua Province, Indonesia based on matK gene
}

\author{
LISYE IRIANA ZEBUA", TRI GUNAEDI, I MADE BUDI ${ }^{1}$, NELLY LUNGA \\ Department of Biology, Faculty of Mathematics and Natural Science, Cenderawasih University. J1 Kamp Wolker Kampus Baru-Waena, Jayapura 99351, \\ Papua, Indonesia. Tel./fax. +62-967-572115. ^email: lispandanus@ gmail.com \\ Manuscript received: 1 May 2019. Revision accepted: 30 October 2019.
}

\begin{abstract}
Zebua LI, Gunaedi T, Budi IM, Lunga N. 2019. The DNA barcode of red fruit pandan (Pandanaceae) cultivar from Wamena, Papua Province, Indonesia based on matK gene. Biodiversitas 20: 3405-3412. The red fruit pandan has been used by the people of Wamena in central highlands of Papua as medicinal plants, food ingredients, and religious ceremonies. Based on morphological characters, there are 39 cultivars of red fruit pandan in New Guinea. A standard method for plant species identification through DNA barcodes has been recommended to use $m a t K$ gene. The research aimed to determine similarities in DNA barcode sequences of six red fruit pandan cultivars with its close relative that listed in NCBI system and to recommend the reliable DNA barcode for identification of this cultivar. Polymerase Chain Reaction was employed DNA to amplify matK gene fragments using an available forward primer (5'CGA TCT ATT CAT TCA ATA TTT C 3') and reverse primer (5'TCT AGC ACA CGA AAGTCG AAG T 3'). The software BLAST, Bioedit, and ClustalX were used to analyze the data. Barcode DNA of red fruit pandan showed 1474 bp nucleotides sequence based on matK gene. An indication of six red fruit pandan cultivars showed that high similarity 99\% with Pandanus conoideus Lam. It can be concluded that matK gene can be used to determine the species level in Pandanus.
\end{abstract}

Keywords: DNA barcode, genes matK, red fruit pandan, Wamena

\section{INTRODUCTION}

Indonesia is one of the mega biodiversity countries. One of the biodiversity plants that have been widely known as a medicinal plant is red fruit pandan (Pandanus conoideus Lam.) (Malik and Lestari 2014). The utilization of red fruit pandan in life is characteristic of Austronesian and Melanesian societies. Traditionally, Pandanus plant is used as a food seasoning, medicine, until the material needs of religious ceremonies (Powell 1976; Milliken 1994; Walter and Sam 2002; Englberger et al. 2003).

The continuous utilization without complete data collection will result in the loss of biodiversity plant, so that data collection on the biodiversity of plants must be done. Red fruit pandan contains essential nutrients, such as beta-carotene, tocopherol, linolenic acid, oleic acid, and kanoat (Budi 2003; Lebang et al. 2004). Currently, the economically extract of red fruit pandan of high value, so it can improve the economy of society. The impact of utilization as a medical plant is the cultivation process of red fruit pandan by local people to meet the market demand.

The red fruit pandan cultivated has the shape, size, and color of the cephalium varied. Morphologically, the color of fruit consists of two groups of color, namely is red and yellow. The red color shows wide variations ranging from red merona to red venetia (Zebua et al. 2009). The Papuan people's understanding of red fruit pandan is so diverse that Stone (1982) tends to refer to the whole variety of red fruit pandan with the name Marita which means the edible Pandanus group. The name is derived from the Pidgin language in Papua New Guinea. Papuans recognize the diversity of red fruit pandan, including short-size fruit, long-size fruit, and medium-size fruit. According to Jebb (1991) and Walter and Sam (2002), it has been known that there are 39 cultivars in Papua and Papua New Guinea.

According to Sofiyanti et al. (2016) and Harsono et al. (2016), prior to the discovery of molecular identification techniques, people have identified plants based on morphological characters. The identification should be supported by those characters such as stems, leaves, flowers, and fruit. Also, if the plants to be identified belong to a genus with many similarities to morphological characters, it would be difficult to distinguish them as different species. Another obstacle is that morphological character-based identification requires specialized skills in taxonomy.

The development of species identification methods has begun from the process of morphological identification to molecular identification based on short DNA sequences called barcodes of DNA (Hebert et al. 2003). DNA barcodes have applicative functions such as for ecological surveys (Dick and Kress 2009), identification of taxa (Lahaye et al. 2008), and confirmation of medicinal plant samples (Xue and Li 2011).

One of the advantages offered by DNA barcoding techniques is that identification can be done without complete organs and anyone can do that, regardless of their expertise in taxonomy (Jarman and Elliott 2000; Hebert et al. 2003; Stoeckle 2003; Ali et al. 2014). In practice, identification techniques accompanied by a complete barcode database as well as other data, such as 
morphological data and other phenotype data is easier. This means that both identification techniques, conventional and molecular, complement each other. In addition, barcoding techniques of DNA used to determine the taxonomic status of an organism cannot replace conventional techniques (Will and Rubinoff 2004; DeSalle 2006; Roslim 2017).

Since the invention of barcode DNA techniques, some DNA barcodes have been developed and stored in the GenBank. The Consortium for the Barcode of Life (CBOL) recommends two standard DNA barcodes to plant identification are the maturase genes $\mathrm{K}$ (matK) and ribulose-1,5-bisphosphate carboxylase $(r b c L)$. Those genes were chosen based on several considerations, such as the ability to recover, the quality of the sequence, and the ability to distinguish species. Both genes are part of the plant genome (CBOL Plant Working Group 2009).

The $m a t K$ gene encodes the maturase enzyme and has a higher rate of substitution mutations than $r b c L$. As a result, the $m a t K$ variation between species is higher than $r b c L$, so the mat $K$ is often used in the study of plant phylogenetic and plant molecular identification. The $r b c L$ gene encodes a large subunit of the ribulose bisphosphate carboxylase enzyme that plays an important role in photosynthesis. The sequence of $r b c L$ sequences is more conservative than the sequence of matK (Fazekas et al. 2008; Lahaye et al. 2008; Patwardhan et al. 2014; Guo et al. 2016).

This paper reveals the use of matK DNA barcode to determine similarities of six red fruit pandan cultivars with it close relative that listed in the NCBI system and to recommend the reliable DNA barcode for identification of this cultivar.

\section{MATERIALS AND METHODS}

\section{Plant materials}

The plant materials used in this study were six red fruit Pandan cultivars collected from Kelila and Kurulu Subdistricts, Jayawijaya District, Papua Province, Indonesia (Figure 1).

The area is at an altitude of 2,300 $\mathrm{m}$ above sea level. The six red fruit pandan has been cultivated in the garden by local people. The primer for the matK used in this study was designed based on the DNA sequences that were available in the GenBank database (Table 1). Sequences of matK from some accession used to create phylogenetic trees were derived from the GenBank.
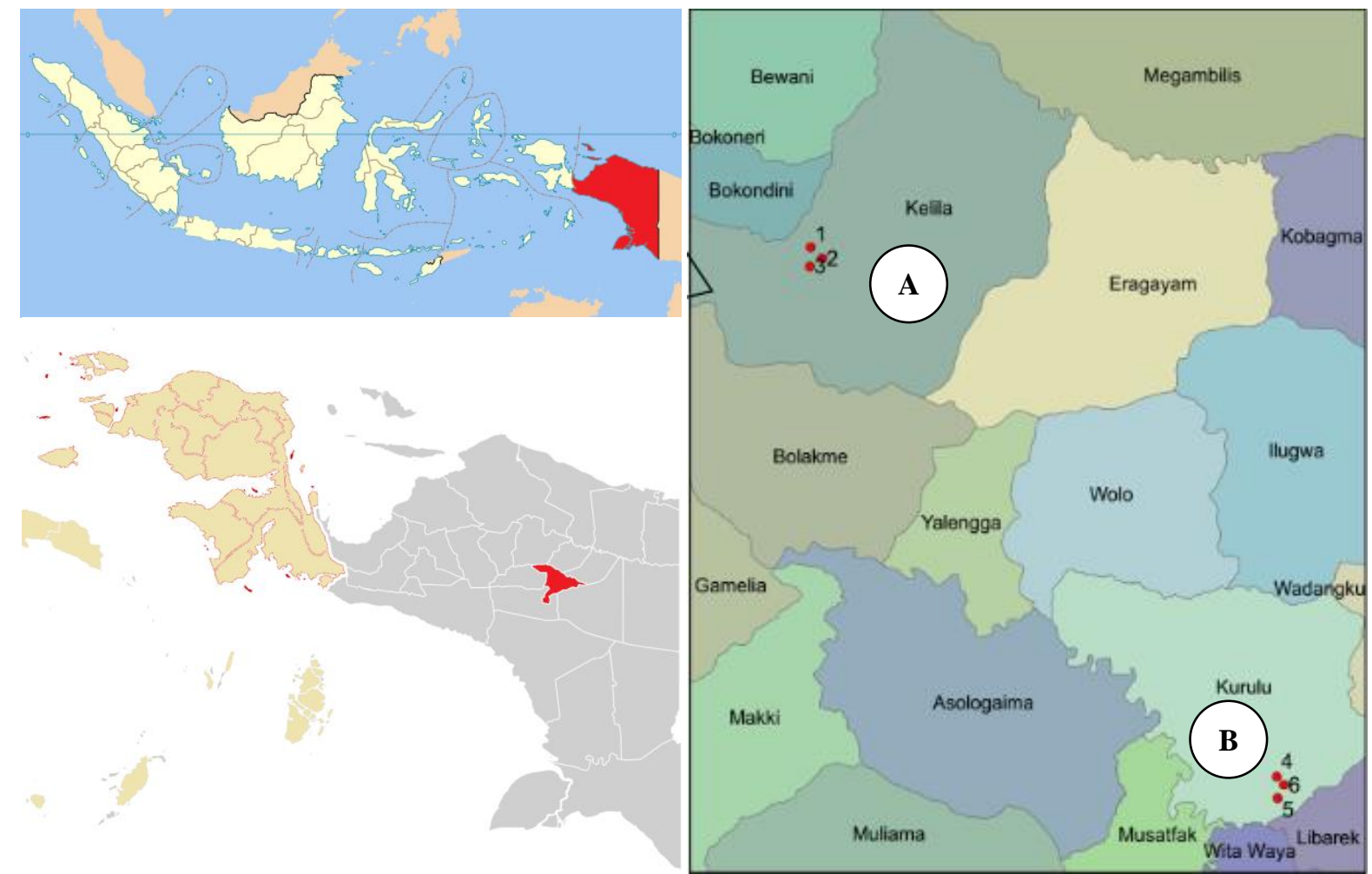

Figure 1. Location of six red fruit cultivars collection in Jayawijaya District, Papua Province, Indonesia. A. Kelila Sub-district

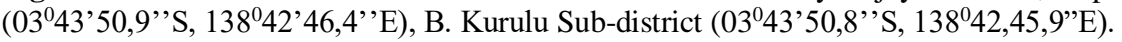

Table 1. Primers for amplification of $m a t K$

\begin{tabular}{|c|c|c|c|}
\hline Primers & 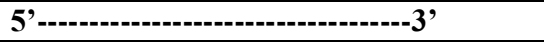 & Annealing temperature $\left({ }^{\circ} \mathrm{C}\right)$ & Regions \\
\hline $\mathrm{P}-m a t K-\mathrm{F}$ & CGA TCT ATT CAT TCA ATA TTT C & 50,0 & maturase $\mathrm{K}$ \\
\hline $\mathrm{P}-m a t K-\mathrm{R}$ & TCT AGC ACA CGA AAGTCG AAG T & & \\
\hline
\end{tabular}




\section{Total DNA isolation}

The total DNA was extracted from fresh leaves using DNeasy plant mini kit with the procedure according to manufacturing instruction QIAGEN product. The quality and the quantity of total DNA were predicted using electrophoresis on $1 \%$ agarose gel in $1 \mathrm{X}$ TAE buffer (TrisAcetate-EDTA $\mathrm{pH}$ 8.3) at $100 \mathrm{~V}$ for 30 minutes. The band was recorded MacroVue UV-20. The DNA absorbance was measured using a spectrophotometer at a wavelength of 260 and $280 \mathrm{~nm}$. The result of absorbance is calculated by the formula (Abs $260 \times 50 \mu \mathrm{g}) \times \mathrm{FP}$.

\section{The DNA amplification using Polymerase Chain Reaction (PCR) technique}

The total DNA was amplified in $1 \mu$ template DNA $100 \mathrm{ng} / \mu \mathrm{l}, 5 \mu \mathrm{K}$ KAPA 2G Fast Ready Mix PCR, 0,25 $\mu \mathrm{l}$ primer forward and reverse primers with a $10 \mathrm{pmol} / \mu \mathrm{l}$ respectively, and $3,5 \mu \mathrm{l} \mathrm{dH}_{2} \mathrm{O}$. The PCR analysis was conducted with the following predenaturation conditions at $95^{\circ} \mathrm{C}$ for 5 minutes, followed by $95^{\circ} \mathrm{C} 3$ seconds for denaturation, 30 seconds at $50^{\circ} \mathrm{C}$ for annealing temperature P-matK-F (CGA TCT ATT CAT TCA ATA TTT C) and PmatK-R (TCT AGC ACA CGA AAGTCG AAG T) (Table 1.), 30 seconds at $72^{\circ} \mathrm{C}$ extension for 35 replicates. The PCR process was ended with 1 cycle of post-PCR for 5 minutes at $72^{\circ} \mathrm{C}$, and cooling for 10 minutes at $20^{\circ} \mathrm{C}$.

\section{Quantify PCR}

The PCR products were migrated using $1 \%$ agarose gels in $1 \mathrm{X}$ TAE buffer at $100 \mathrm{~V}$ for 30 minutes. Then, the band was stained using $1 \mathrm{mg} / \mathrm{ml} \mathrm{EtBr}$ (ethidium bromide) solution for 5 minutes, then visualized on the UV transilluminator (Uv-20 $230 \mathrm{~V}$, Hoefer Pharmacia Biotech Inc.), and then documented using a MacroVue UV-20.

\section{PCR purification and sequencing}

The resulting PCR products were the DNA band of 1000 base pairs (bp), then sent to PT Bioneer Indonesia to be purified and sequenced. Sequencing was performed using the PCR primer pairs.
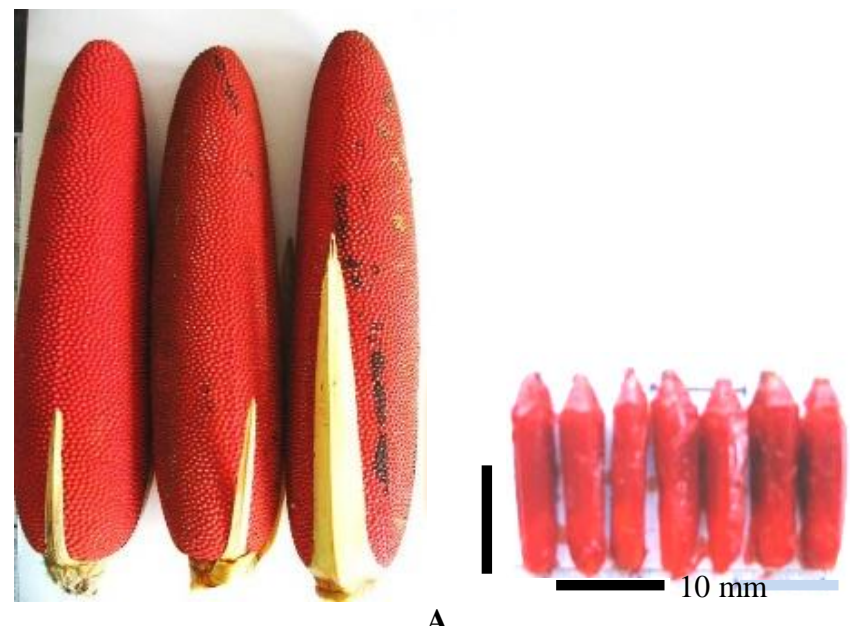

A

A

Figure 2. Samples of red fruit pandan from Wamena. A. The red colour variation, B. The yellow colour variation. Bar $=10 \mathrm{~mm}$

\section{Data analysis}

The DNA sequences were then analyzed and aligned using BioeEdit version 7.0 software (Hall 1999). The sequences were then analyzed using BLAST program Basic Local Alignment Search Tool (NCBI) to search the similarity between the six sequences and the sequences deposited in the GenBank database. A phylogenetic tree or cladogram was then created using software Clustal $\mathrm{X}$ vertion $1.62 \mathrm{~b}$. The trees were reconstructed by nucleotide sequences using algorithms neighbor-joining method with 1000 x replication (Saitou and Nei 1987). Cyclanthus bipartitus (accession number. KP083038.1) which is a member of Cylanthaceae family was used as outgroup.

\section{RESULTS AND DISCUSSION}

\section{Morphological characters of red fruit pandan cultivar from Wamena}

The local people of Wamena have known the red fruit pandan as food sources. They are able to recognize and classify it into the morphological features of the cephalium and drupe (Zebua and Walujo 2016). The size and color of cephalium is varied. The cephalium can be a red and yellow color. The length of cephalium ranges $30-90 \mathrm{~cm}$, the drupe length ranges from 14-16 mm (Figure 2).

The length of the six cephalium red pandanus cultivars ranged from $36-90 \mathrm{~cm}$, the length of the drupe ranged from 11.34-19.79 $\mathrm{mm}$ and the width of the drupe ranged from 1.09-5.01 mm. The colors of cephalium are dark yellow, rosy red, pompei red, Indian red, bright red, and venetia red (Table 2).

\section{DNA profiles}

The result of the amplification of the matK gene against six red fruit pandan shows the readable DNA bands measuring around 1000-1474 bp. The success of amplification with PCR is evidenced by the process of sequencing the red pandan fruit product with good quality (Figure 3).

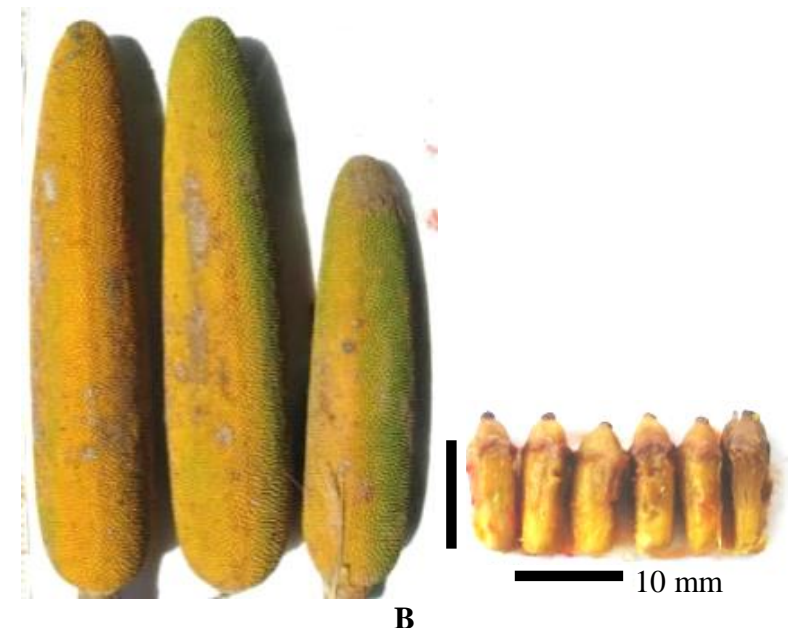


Table 2. The morphology of cephalium and drupe for six cultivar of red fruit pandan from Wamena

\begin{tabular}{lccc}
\hline Accession & $\begin{array}{c}\text { Length of } \\
\text { cephalium }(\mathbf{c m})\end{array}$ & $\begin{array}{c}\text { Size of } \\
\text { drupe }(\mathbf{m m})\end{array}$ & $\begin{array}{c}\text { Colour of } \\
\text { cephalium }\end{array}$ \\
\hline LC491423 (M1) & $36-46$ & $11.34-13.57 \times 3.02-5.01$ & Rosy \\
LC491424 (M2) & $41-54$ & $11.25-14.84 \times 3.15-5.13$ & Dark yellow \\
LC491425 (M4) & $74-80$ & $14.77-17.54 \times 2.19-3.12$ & Pompei red \\
LC491426 (M6) & $80-90$ & $14.36-17.33 \times 2.21-3.12$ & Indian red \\
LC491427 (M8) & $73-82$ & $11.54-14.79 \times 1.09-3.36$ & Bright red \\
LC491428 (M9) & $76-77$ & $12.71-19.79 \times 1.12-3.50$ & Venetia red \\
\hline
\end{tabular}

\section{Analysis of matK sequences of red fruit pandan cultivars}

The $\operatorname{mat} K$ sequences of red fruit pandan has a size of 1474 bp that have been registered in GenBank with accession number JX286789.1 (Figure 4). The sequences alignment used a BLAST analysis which showed that six red fruit pandan cultivars from Wamena had a high similarity (ident 99\%) with Pandanus conoideus. This is supported by 87 to $89 \%$ query coverage value, E-value 0.0 , maximum score, and the total score (Table 3).

Based on the BLAST analysis, the total alignment score of all six red pandanus cultivars from the database sequence that matches the nucleotide sequence at GeneBank was 1474 bp, then the query coverage value ranged from 87 to $89 \%$, and the E-value showed a value of 0.0 (Table 3).

According to Miller et al. (1990) and Claveri and Notredame (2003), the higher score obtained the higher the homology of the two sequences, while the query coverage is a percentage of the long nucleotide aligned with the database in the BLASTn analysis. The E-value that gives statistically significant to both sequences. The E-value indicates the homologous level between the lower sequences, whereas the lower of the E-value indicates that the two sequences are identical. The similarity value of the six red pandan cultivars is $99 \%$ which is similar to JX286789.1 sequence, namely Pandanus conoideus in GenBank (Figure 4).

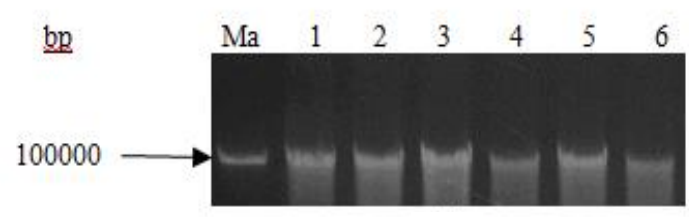

A

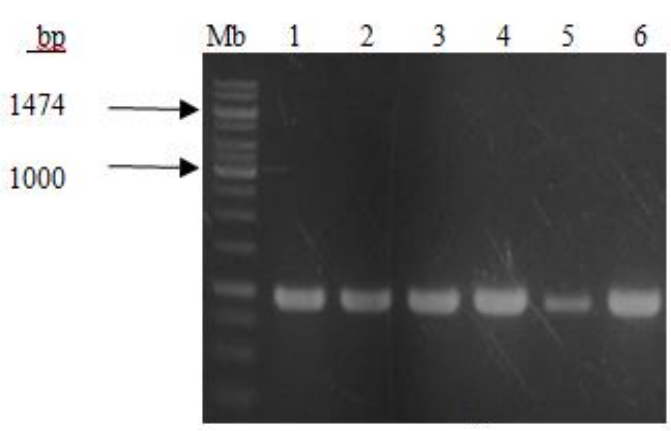

B

Figure 3. Profile of the total DNA (A) and PCR product of six red fruit pandan cultivars (B). (Ma) DNA $\lambda 10$ ng/ $\mu$ l, (1-6) fragment of mat $K$ of red fruit pandan cultivar that migrated on $1 \%$ agarose gels in $1 \mathrm{X}$ TAE buffer, $(\mathrm{Mb}) 1 \mathrm{~kb}$ DNA Ladder.

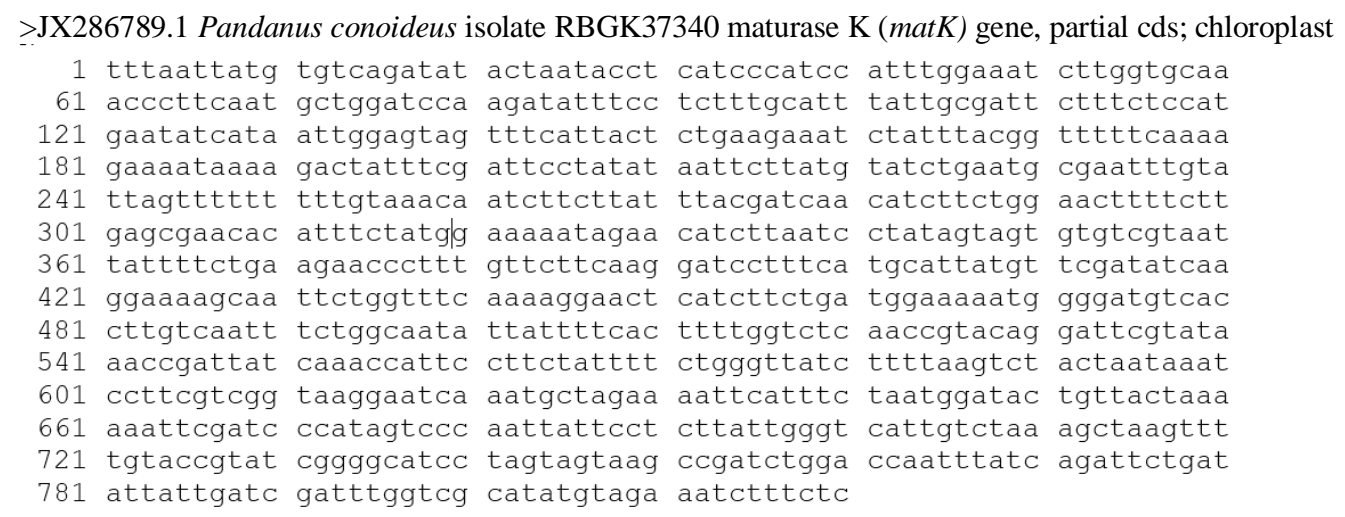

Figure 4. The matK sequences of Pandanus conoideus have been registered in GenBank with accession number JX286789.1 
Table 3. BLASTn analysis of $m a t K$ sequence of red fruit pandan

\begin{tabular}{lcccccc}
\hline $\begin{array}{c}\text { Description } \\
\text { (accesion number) }\end{array}$ & Max score & Total score & $\begin{array}{c}\text { Query coverage } \\
(\boldsymbol{\%})\end{array}$ & E-value & $\begin{array}{c}\text { Similarity } \\
(\boldsymbol{\%})\end{array}$ & $\begin{array}{c}\text { GenBank accession } \\
\text { number }\end{array}$ \\
\hline LC491423 (M1) & 1474 & 1474 & 89 & 0.0 & 99 & JX286789.1 \\
LC491424 (M2) & 1474 & 1474 & 87 & 0.0 & 99 & JX286789.1 \\
LC491425 (M4) & 1474 & 1474 & 89 & 0.0 & 99 & JX286789.1 \\
LC491426 (M6) & 1474 & 1474 & 87 & 0.0 & 99 & JX286789.1 \\
LC491427 (M8) & 1474 & 1474 & 88 & 0.0 & 99 & JX286789.1 \\
LC491428 (M9) & 1474 & 1474 & 89 & 0.0 & 99 & JX286789.1 \\
\hline
\end{tabular}

Tabel 4. The similarity value of the matK gen and the number of different nucleotides in the six red fruit pandan from Wamena.

\begin{tabular}{lccccccc}
\hline Accession & JX & M1 & M2 & M4 & M6 & M8 & MS9 \\
\hline JX286789.1 & - & $1 / 820$ & $1 / 820$ & $1 / 820$ & $1 / 820$ & $1 / 820$ & $1 / 820$ \\
LC491423 (M1) & 99.88 & - & $0 / 917$ & $0 / 917$ & $3 / 917$ & $0 / 917$ & $0 / 916$ \\
LC491424 (M2) & 99.88 & 100 & - & $0 / 920$ & $14 / 932$ & $3 / 923$ & $0 / 916$ \\
LC491425 (M4) & 99.88 & 100 & 100 & - & $5 / 920$ & $0 / 918$ & $0 / 916$ \\
LC491426 (M6) & 99.88 & 99.67 & 98.50 & 99.46 & - & $4 / 923$ & $2 / 916$ \\
LC491427 (M8) & 99.88 & 100 & 99.67 & 100 & 99.57 & - & $0 / 916$ \\
LC491428 (M9) & 99.88 & 100 & 100 & 100 & 99.78 & 100 & - \\
\hline
\end{tabular}

\section{Phylogenetic analysis}

Phylogenetic analysis is inseparable from the process of biological evolution. Evolution is a gradual process of an organism that enables simple species to become more complex through the accumulation of changes from several generations. Descendants will have some differences from their ancestors because they are changing in evolution (Estabrook 1984). In studying genetic variation and differentiation among populations, genetic distance can be calculated from the number of polymorphic base differences in a gene locus of each population based on DNA sequence (Cavalli 1997).

Phylogenetic analysis is carried out through the construction of evolutionary history and the relationship between offspring and their ancestors based on the similarity of characters as the basis of comparison. An organism that is identified using short DNA sequences located within the genome of cell nuclei and plastids is called the DNA barcode technique (White et al. 1990; Hebert et al. 2003; Buerki et al. 2012; Patwardhan et al. 2014; Guo et al. 2016). In terms of interspecies variation, mat $K$ barcode has a better differentiating ability for sample identification in this study.

The sequence of DNA of six red fruit pandan cultivars will be converted into the distance matrix (Table 4) and cladogram (Figure 5), and they will be described the similarity between accessions, to show a large number of different nucleotides.

Based on the number of nucleotide sequences from six red pandan cultivars compared to the number of nucleotide sequences from GenBank, there is only 1 nucleotide sequence that is different from 820 nucleotide sequences that are read at GenBank. This is reinforced by the similarity value of $99.88 \%$ of the nucleotide sequences of six red pandan cultivars similar to the nucleotide sequences of JX286789.1 accession number in GenBank (Table 4). The difference in the number of nucleotide sequences between M1 cultivar and M6 cultivar was 3 nucleotide sequences from 917 sequences that were read with similarity values of $99.67 \%$. The difference in the number of nucleotide sequences between M6 cultivar and M2 cultivar is 14 nucleotide sequences from 932 read sequences, with a similarity value of $98.50 \%$. The difference in the number of nucleotide sequences between M6 cultivar and M4 cultivar is 5 nucleotide sequences from 920 read sequences, with $99.46 \%$ similarity values. The difference in the number of nucleotide sequences between M8 cultivar and M2 cultivar is 3 nucleotide sequences from 932 read sequences, with a similarity value of $98.50 \%$. The difference in the number of nucleotide sequences between M8 cultivar and M6 cultivar is 4 nucleotide sequences from 923 read sequences, with $99.57 \%$ similarity values. The difference in the number of nucleotide sequences between M9 cultivar and M6 cultivar is 2 nucleotide sequences from 916 read sequences, with a similarity value of $99.78 \%$ (Table 4).

The similarity value of the matK gene showed that the six red fruit pandan were $98 \%$ to $99 \%$ similar to the accession number from GeneBank, i.e. JX286789.1 (Table 4). The $\operatorname{mat} K$ is a gene with high variation compared to other genes in the plant chloroplast genome so that it can be used for the identification and verification of plants (Lambowitz and Zimmerly 2004; Zoschke et al. 2010). The $m a t K$ gene has been used for molecular identification analysis of the legume plants (Wojciechowski et al. 2004), Angiosperms (Yu et al. 2011), and several species in the genus Vicia (Raveendar et al. 2015). Verification is helpful to increase public knowledge that matK sequences can be used for molecular identification of the plant. Identification techniques that when the identification process is not equipped with other plant parts such as leaves, stems, flowers, and fruit, such as in red pandan cultivars, the use of DNA barcode analysis is needed to assist the verification process in intraspecific identification (Stone 1974, 1983,1993; Buerki et al. 2012).

The advantages of the plant molecular identification using barcoding DNA technique is as follows: 1) the molecular identification of plant can be done by anyone, whether a taxonomist or not a taxonomist; 2) the DNA sequences or the DNA barcode is not influenced by the environment; 3) molecular identification is easy and fast if DNA sequence database of target species is provided. A search in NCBI for matK sequences of six red fruit pandan 
cultivars yielded a $99.88 \%$ (identical) similarity to Pandanus conoideus in the NCBI GenBank, although morphologically the red fruit pandan has the shape, size, and color of the cephalium varied. The color of fruit consists of two groups of color, namely is red and yellow. The red color shows wide variations ranging from red merona to red venetia (Zebua et al. 2009). This result shows that $m a t K$ sequences can be used for identification at the intra-species level. The matK sequences have a high rate of evolution and the sequence of sequences is more varied so that matK sequences are often used in plant phylogenetic studies and molecular identification of plants (Patwardhan et al. 2014; Guo et al. 2016).

The phylogenetic tree based on the sequence matK shows a relationship between 27 accessions of reference belonging to the Pandanus listed in the NCBI system with six red fruit pandan cultivars from Wamena (Figure 5). To find out the kinship of a species can be done by constructing phylogenetic trees. The phylogenetic tree is a picture that occurs in a group of living creatures from the same ancestors (Ochieng et al. 2007). Based on phylogenetic tree, the six red pandan cultivars from Wamena are monophyletic groups and located in the second clade position together with Pandanus conoideus isolate RBGK37340 with support of 55-79\% bootstrap value. According to Dharmayanti (2011), the bootstrap value shows the number of frequencies of the branching pattern that appear at a node in the original tree that results in repeated repetitions. If the bootstrap value is more than $95 \%$, it can be concluded that the node has a high level of confidence.

Based on phylogenetic tree analysis of mat $K$ sequences using Neighbor-Joining, there were 3 clades formed, in which the six red fruit pandan cultivars were positioned in the second clade with Pandanus conoideus. Cyclanthus bipartitus as outgroup belongs to the same order as the Pandanus.

According to Walter and Sam (2002), P. conoideus has 39 variations of cephalium, which are distinguished by size up to the color of the cephalium. According to Zebua et al. (2010), cephalium colors consist of two groups, namely red and yellow. The red color shows a wide variation, from blushing to venetia. A large number of morphological variations that arise cause the plant to be known as a complex Pandanus type (Table 2).

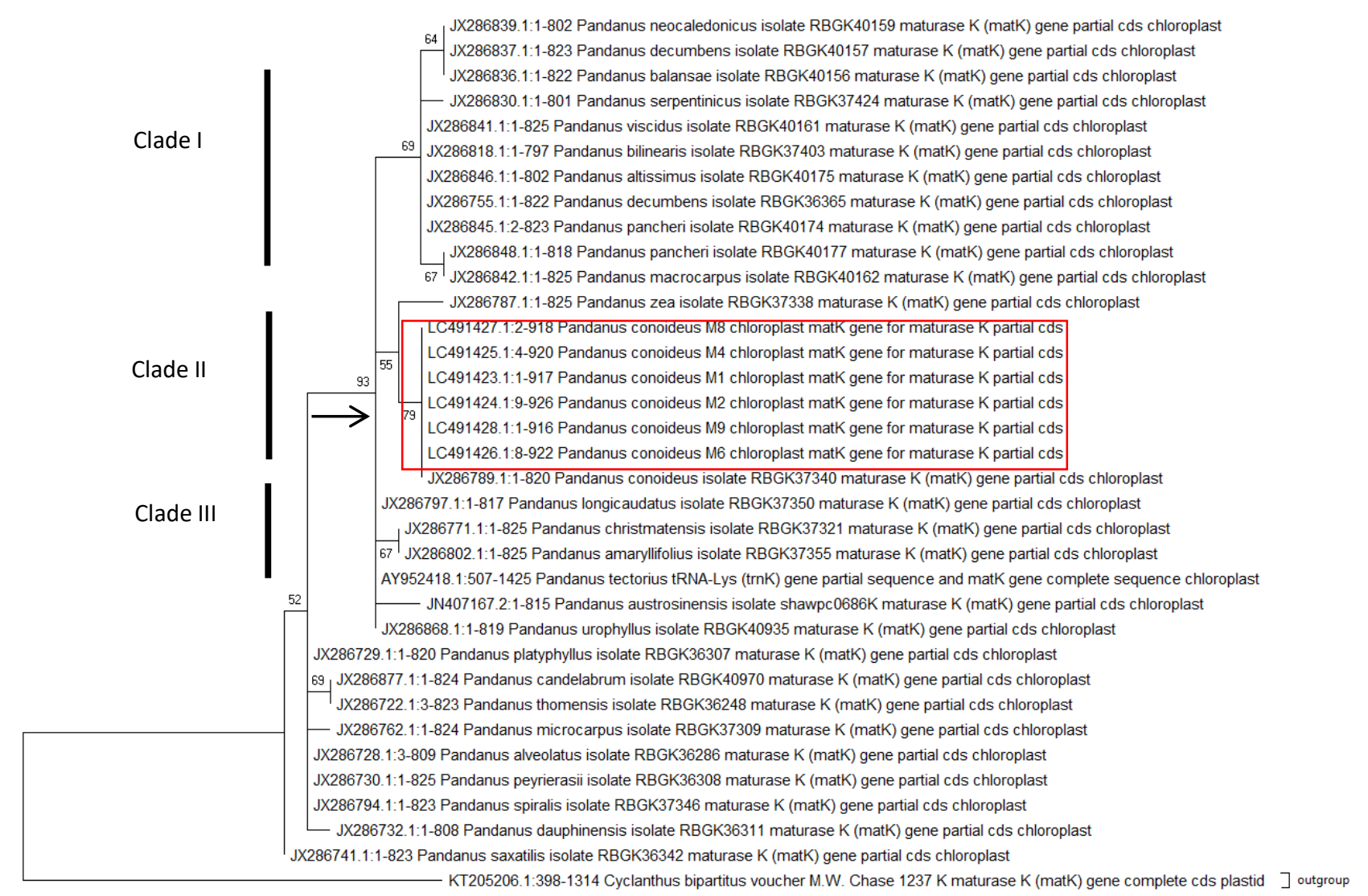

0.01

Figure 4. Phylogenetic tree based on $m a t K$ sequences using Neighbour-Joining analysis with $1000 \mathrm{x}$ replication. The branching number indicated bootstrap value (\%). The arrow indicate is Cyclanthus bipartitus KT205206.1 as outgroup. The scale indicates a substitution rate of 1 per 100 nucleotides in the $m a t K$ sequence. 
Based on the results of genetic diversity analysis of 15 red fruit pandan cultivars using AFLP sequences, it showed DNA banding patterns that were amplified highly polymorphic (Zebua et al. 2010). The difference in the number of polymorphic bands produced by each primer illustrates the complex genome of a plant (Grattapaglia 1992). Several types of pandan are known as complex Pandanus including Pandanus tectorius Parkinson ex Du Roi, $P$. pedunculatus R.Br., $P$. piniformis Holttum \& H.St.John, and P. spurius (Willd.) Miq. (Thomson et al. 2006).

Based on the analysis of the distance between the red fruit pandan accession is $99 \%$. It means that they are very similar to each other based on the matK sequence (Table $3)$. They are also very similar based on morphological characters (Table 2). Furthermore, phylogenetic analyses show that the six red fruit pandan cultivars are grouped in one group and have similarity to $P$. conoideus than others. These results are in accordance with the results of BLAST analysis and strengthen the taxonomic status of red fruit pandan as $P$. conoideus.

The standard barcode DNA for plant molecular identification is $r b c L$ and $m a t K$ genes (CBOL Plant Working Group 2009). Regardless of the combination of DNA barcodes, plant molecular identification should be complemented and combined with other information about identified species, such as morphological, ecological, and developmental characters (Smith et al. 2005). Those characters complement each other with molecular identification techniques, and morphological identification techniques cannot be replaced by molecular identification techniques (Will and Rubinoff 2004). Molecular identification techniques are essential to assist in the identification of plant specimens that are not equipped with plant part information such as leaves, stems, flowers, and fruit. It is often present in the process of identification of the genus Pandanus which varies greatly morphologically (Stone 1974, 1983, 1993; Buerki et al. 2012).

Recently, updates on phylogenetic analyzes among species and genera have been done in the Pandanaceae using molecular analysis. DNA sequencing used frequently is chloroplast DNA sequence, such as matK, trnQ-rps 16 , and $t r n L-t r n F$. The Pandanaceae were grouped into five groups of genera i.e. Freycinetia, Sararanga, Martellidendron, Pandanus sect. Acrostigma, and most recently of Pandanus (Buerki et al. 2012).

In conclusion, the red fruit pandan cultivars from Wamena have a very wide variety of morphological characters so it is very difficult to identify. Based on the application of barcoding matK gene, the six red fruit pandan cultivars from Wamena can be identified to the species level. The results of phylogenetic tree analysis showed that six red fruit pandan cultivars were grouped in one group with Pandanus conoideus species.

\section{ACKNOWLEDGEMENTS}

This research was funded by a grant from the Ministry of Research, Technology, and Higher Education, Republic of Indonesia (2018) under 'PDUPT'. I would like to thank Kalvin Paiki, Nopinus Kogoya, and Resmin Kogoya, for their assistance in the field; Mb Peppy for technical assistance in the laboratory.

\section{REFERENCES}

Ali MA, Gyulai G, Hidve'gi N, Kerti B, Al Hermaid FMA, Pandey AK, Lee J. 2014. The changing epitome of species identification-DNA Barcoding. Saudi J Biol Sci 21: 204-231.

Budi MI. 2003. The potential of red fruit pandan as an alternative food source to support food security of the people of Papua. National Workshop on Local Specific Food Empowerment. Cooperation participated by Department of Agriculture and Universitas Negeri Papua, Jayapura. [Indonesian]

Buerki S, Callmander MW, Devey DS, Chappell L, Gallaher T, Munzinger J, Haevermans T, Forest F. 2012. Straightening out the screwpines: A first step in understanding phylogenetic relationships within Pandanaceae. Taxon 61(5): 1010-1020.

Cavalli SLL. 1997. Genes, people and languages. Proc Nat Acad Sci 94(15): 7719-7724.

CBOL Plant Working Group. 2009. A DNA barcode for land plants. Proc Nat Acad Sci 106: 12794-12797.

Claverie JM, Notredama C. 2003. Bioinformatics for Dummies Volume 5. Wiley Publishing, Indianapolis.

DeSalle R. 2006. Species discovery versus species identification in DNA barcoding efforts: response to Rubinoff. Conserv Biol 2(5): 15451547.

Dharmayanti NLPI. 2011. Molecular phylogenetic: Organism taxonomy methods based on evolutionary history. Wartazoa 21(1): 1-10.

Dick CW, Kress WJ. 2009. Dissecting tropical plant diversity with forest plots and a molecular toolkit. Bioscience 59: 745-755.

Englberger L, Fitzgerald MH, Marks GC. 2003. Pacific Pandanus fruit: An ethnographic approach to understanding an overlooked source of provitamin A carotenoids. Asia Pacific J Clin Nutr 12: 38-44.

Estabrook G. 1984. Phylogenetic tree and character-state tree. In: Duncan T, Stuessy T (eds) Perspective on the Reconstruction Evolutionary History Cladistics. Columbia University Press.

Fazekas AJ, Burgess KS, Kesanakurti PR, Graham SW, Newmaster SG. 2008. Multiple multilocus DNA barcodes from the plastid genome discriminate plant species equally well. PloS ONE 3: e2802.

Grattapaglia D. 1992. Mapping in woody plant with RAPD marker: application to breeding in forestry and horticulture. In: application of RAPD technology to plant breeding. Joint Plant Breeding Symposia Series. Minneapolis, Minnesota.

Guo Y-Y, Huang L-Q, Liu Z-J, Wang X-Q. 2016. Promise and challenge of DNA barcoding in Venus slipper (Paphiopedilum). PLoS ONE 11(1): e0146880. DOI: 10.1371/journal.pone.0146880.

Hall TA. 1999. BioEdit: A user-friendly biological sequence alignment editor and analysis program for Windows 95/98/NT. Nucl Acid Sci 41: 95-98.

Harsono T, Pasaribu N, Sobir, Fitmawati. 2016. Diversity of gandaria (Bouea) based on morphological characters in Indonesia. SABRAO J Breed Genet 48(4): 504-517.

Hebert PDN, Cywinska A, Ball SL, deWaard JR. 2003. Biological identification through DNA barcodes. Proc R Soc London B 270: 313-321.

Jarman SN, Elliott NG. 2000. DNA evidence for morphological and cryptic Cenozoic speciations in the Anaspididae, living fossils from the Triassic. J Evol Biol 13: 624-633.

Jebb M. 1991. A Field guide to Pandanus in New Guinea, The Bismark Archipelago \& The Solomon Islands. Christensen Research Institute, Madang.

Lahaye R, Van der Bank M, Bogarin D, Warner J, Pupulin F, Gigot G, Maurin O, Duthoit S, Barraclough TG, Savolainen V. 2008. DNA 
barcoding the floras of biodiversity hotspots. Proc Nat Acad Sci USA 105 (8): 2923-2928.

Lambowitz A, Zimmerly M. 2004. Mobile Group II Introns. Ann Rev Genet 38: 1-35.

Lebang A, Amarudin J, Limbongan GI, Kore S, Pambunan, Budi IM. 2004. Proposed release of varieties of red fruit pandan Mbarugum. BPSP Cooperation on Food Crops and Horticulture of Papua Province, BPTP Papua, and Cenderawasih University, Jayapura. [Indonesian]

Malik M, Lestari RHS. 2004. Potency of red fruit pandan and prospect of development in Papua Province. Proceedings of the Nasional Seminar on Genetic Resources for Agriculture. Technological Agriculture Assessment Center Papua, Jayapura. [Indonesian].

Miller G, Beckwith R, Fellbaum C, Gross D, Miller K. 1990. Introduction to WordNet: An On-line Lexical Database. Int J Lexicograph 3 (4): 235-244.

Milliken W. 1994. Ethnobotany of the Yali of West Papua. Royal Botanic Gardens, Edinburgh.

Ochieng JW, Murigai AWT, Ude GN. 2007. Review: phylogenetics in plant biotechnology: principles, obstacles, and opportunities for resource poor. Afr J Biotechnol 6 (6): 639-649.

Patwardhan A, Samit R, Amit R. 2014. Molecular markers in phylogenetic studies-a review. J Phylogen Evol Biol 2: 131.

Powell JM. 1976. Ethnobotany. In: Paijman K (eds) New Guinea Vegetation. Australian National Univ. Pres, Canberra.

Raveendar S, Lee JR, Park JW, Lee GA, Jeon YA, Lee YJ, Cho GT, Ma KH, Lee SY, Chung JW. 2015. Potential use of ITS2 and $m a t K$ as a two-locus DNA barcode for Identification of Vicia species. Plant Breed Biotech 3 (1): 58-66.

Roslim DI. 2017. Identification of pandan plant (Benstonea sp.) from Riau, Indonesia using three DNA barcodes. SABRAO J Breed Gen 49(4): 346-360.

Saitou N, Nei M. 1987. The neighbor-joining method: A new method for constructing phylogenetic trees. Mol Biol Evol 4: 406-425.

Smith MA, Fisher BL, Hebert PDN. 2005. DNA barcoding for effective biodiversity assessment of a hyperdiverse arthropod group: The ants of Madagascar. Phil Trans R Soc London B: Biol Sci 360 (1462): 1825-1834.

Sofiyanti N, Mat-Salleh K, Mahmud K, Mazlan NZ, Hasein MRA, Burslem DFRP. 2016. Rafflesia parvimaculata (Rafflesiaceae), a new species of Rafflesia from Peninsular Malaysia. Phyotaxa 253 (3): $207-$ 213.

Stoeckle M. 2003. Taxonomy, DNA, and the barcode of life. BioSci 53: 9.

Stone BC. 1974. Toward an improved infra-generic classification in Pandanus (Pandanaceae). Bot Jahrbucher Syst 94: 459-540.
Stone BC. 1982. New Guinea Pandanaceae: First approach to ecology and biogeography. In: Gressit JL (eds) Biogeography and Ecology of New Guinea. Dr. W. Junk Publisher, The Hague. Monogr Biol 42: 401-436.

Stone BC. 1983. Some new and critical Pandanus species of subgenus Acrostigma I, Supplement to revisio Pandanacearum. Gard Bull Sing 36: 205-212.

Stone BC. 1993. Studies in Malesian Pandanaceae 21. The genus Pandanus in Borneo. Sandakania 2: 2-84.

Thomson LAJ, Englberger L, Guarino LT, Thaman RR, Elevitch C. 2006. Pandanus tectorius (Pandanus), ver. 1.1. In: Elevitch C (eds.). Traditional trees of Pacific Islands: Their culture, environment, and use. Permanent Agric Res, Honolulu.

Walter A, Sam C. 2002. Fruit of Oceania. ACIAR Monograph No. 85, ACIAR, Canberra.

White TJ, Bruns T, Lee S, Taylor J. 1990. Amplification and direct sequencing of fungal ribosomal RNA genes for phylogenetics. In: PCR Protocol: A Quite Methods and Application. Academic Press, Inc., New York.

Will KW, Rubinoff D. 2004. Myth of the molecule: DNA barcodes for species cannot replace morphology for identification and classification. Cladistics 20: 47-55.

Wojciechowski MF, Lavin M, Sanderson MJ. 2004. Phylogeny of legumes (Leguminosae) based on analysis of the plastid matK gene resolves many well-supported subclades within the Family. Am J Bot 91 (11): 1846-1862.

Xue CY, Li DZ. 2011. Use of DNA Barcode sensu lato to identify traditional Tibetan medical plant Gentianopsis paludosa (Gentianaceae). J Sys Evol 49 (3): 267-270.

Yu J, Xue JH, Zhou SL. 2011. New universal matK primers for DNA barcoding angiosperms. J Syst Evol 49(3): 176-181.

Zebua LI, Supriatna J, Walujo EB, Chikmawati T. 2010. Ethnobotany and Morphogenetic Diversity of Pandanus conoideus from Papua. [Dissertation]. University of Indonesia, Depok. [Indonesian]

Zebua LI, Supriatna J, Walujo EB, Chikmawati T. 2009. Diversity of red fruit pandan In Papua, Indonesia. International Seminar the $2^{\text {nd: Joint }}$ Seminar UI-FTS UKM at Bangi Campus, Malaysia.

Zebua LI, Waluyo EB. 2016. Traditional Papuan knowledge in recognizing, classifying, and utilizing red fruit pandan. J Biol Papua 8 (1): 23-27. [Indonesian]

Zoschke R, Nakamurab M, Lierea K, Sugiurah M, Bornera T, SchmitzLinnewebera C. 2011. An organellar maturase associate with multiple group II introns. Proc Natl Acad Sci USA 107 (7): 3245-3250. 